\title{
Experiences in Implementing an NSF/REU Site on Interdisciplinary Water Sciences and Engineering during 2007-13
}

\section{Dr. Vinod K Lohani, Virginia Tech}

Dr. Vinod K Lohani is a professor in the Engineering Education Department and an adjunct faculty in the Civil and Environmental Engineering at Virginia Tech. His research interests are in the areas of sustainability, computer-supported research and learning systems, hydrology, and water resources. In a major (\$1M+, NSF) curriculum reform and engineering education research project from 2004 to 2009, he led a team of engineering and education faculty to reform engineering curriculum of an engineering department (Biological Systems Engineering) using Jerome Bruner's spiral curriculum theory. Currently, Dr. Lohani leads an NSF/REU Site on "interdisciplinary water sciences and engineering" which has already graduated 56 excellent undergraduate researchers since 2007. This Site is renewed for the third cycle which will be implemented during 2014-16. He also leads an NSF/TUES type I project in which a real-time environmental monitoring lab is being integrated into a freshman engineering course, a seniorlevel Hydrology course at Virginia Tech, and a couple of courses at Virginia Western Community College, Roanoke for enhancing water sustainability education. He is a member of ASCE and ASEE and has published $70+$ refereed publications. 


\title{
Experiences in Implementing an NSF/REU Site on Interdisciplinary Water Sciences and Engineering during 2007-13
}

\begin{abstract}
This paper summarizes the experiences of the author in implementing a successful NSF/REU Site on Interdisciplinary Water Sciences and Engineering for 6 years at Virginia Tech. The goal of the Site is to train REU fellows in water research using interdisciplinary projects. Site activities included: 1) 10-week long research projects supervised by faculty and graduate student mentors from five departments, 2) professional development activities including seminars and field trips, 3 ) training to communicate scientific information through research papers, YouTube videos and oral presentations, and 4) social and cultural activities for professional growth and bonding of REU fellows. Eleven faculty ( 6 women and 5 men) and their graduate students from diverse academic disciplines including engineering education, civil and environmental engineering, biological sciences, geosciences, and crop and soil environmental sciences directed REU fellows' research and two external experts assisted in program assessment. Fifty-six REU fellows, including 59\% from minorities including women, from 40+ academic institutions all over the country graduated from this Site during the summers of 2007, 08, 09, 11, 12, and 13. Six

Research Proceedings, one for each summer, and 40 publications document research findings of the Site. A summary of Site assessment activities and findings, tracking results of REU fellows' academic/professional career, and lessons learned are included.
\end{abstract}

\subsection{Introduction}

In 2008 the US National Academy of Engineering (NAE) announced 14 Grand Challenges in engineering that are awaiting solutions in the 21 st century. This list includes the challenge to "Provide Access to Clean Water" . Water is the critical element for supplying food and energy, safeguarding human health, and maintaining national security. Increasing pressures for water demand worldwide present challenges to scientists to attain sustainable management of water resources. A recent United Nations report projects that virtually every nation will face a water supply problem within the next 20 years. It is also estimated that currently more than a billion people have little access to clean drinking water and that 2 billion live in conditions of water scarcity $^{2}$. A key component to any solutions related to the sustainability of the water resources is to educate our youth about the interdisciplinary aspects of water research and to train them as future professionals who will develop appropriate solutions to address these "water-related" challenges at national and global levels.

The author and a colleague (Dr. Tamim Younos) took lead in establishing a NSF/Research Experiences for Undergraduates (REU) Site on Interdisciplinary Water Sciences and Engineering beginning in 2007 at Virginia $\mathrm{Tech}^{3}$. Several faculty members representing various departments including Civil \& Environmental Engineering, Engineering Education, Geo-sciences, Biology, and Crop \& Soil Environmental Sciences agreed to mentor undergraduate students. First cycle of the Site was implemented from 2007-09 with 26 graduates $^{3}$. A renewal proposal was submitted in fall 2009 which was not successful. The renewal proposal, led by the author, was re-submitted in fall 2010 which was successful. Second cycle of the Site was implemented from 2011-13 with 30 REU fellows. In fall 2013, a Site renewal proposal was submitted and at the time of this writing the NSF is in the process of recommending continuation of this Site for the next 3 years (201416). Altogether these three REU Site cycles have generated $\$ 1 M+$ support for undergraduate 
research at Virginia Tech. At the end of $3^{\text {rd }}$ cycle in 2016, this Site would have graduated 86 REU alumni.

In terms of the history of the REU program, the NSF established an undergraduate research program (URP) in 1958 which was discontinued in 1979. The URP program did not emphasize recruiting underrepresented students and the institutions receiving the URP funds recruited students internally ${ }^{4}$. In 1986, the NSF established the REU program emphasizing recruitment of students from underrepresented groups and required the grantee institutions to recruit most of the research participants from outside the host institutions ${ }^{4}$. Raicu and Furst ${ }^{5}$ have described a model for interdisciplinary undergraduate research by engaging students in studies targeted at exploring the frontier between computer science and medicine. In a study reported by Gonzalez-Espada and Zaras $^{6}$, the authors found an overwhelming evidence to show that the REU programs at National Weather Center (NWC) are having a positive impact on students' decisions to pursue careers in science. In describing their experiences of a successful REU Site in computer science and engineering, two authors ${ }^{7}$ have analyzed the opinions of the faculty mentors to highlight their motivation and expectations from the program and made eleven recommendations to fulfill mentors' expectations. Examples include: Collect information about the mentor's projects and requirements as soon as possible and incorporate them in the recruitment process and Provide mentors with some sort of gift or token of appreciation. The authors have also discussed strategies ${ }^{8}$ to improve participation of underrepresented groups in computer science and engineering through undergraduate research. In a paper by Packham, et al. ${ }^{9}$, the authors have discussed the challenges, strategies, and benefits of robust research programs for undergraduates. In a quarterly publication by the Council on Undergraduate Research (CUR), Beninson et al. ${ }^{10}$ have presented the evaluation results, based on data collected during summers of 2006 through 2009, of the REU Sites funded/co-funded by the Directorate for Biological Sciences at NSF. It was found that these Sites engaged a diverse group of students $(>40 \%)$ coming from the groups that are underrepresented in science. It was also reported that the number of international REU Sites has decreased from 2006 to 2009 which is inconsistent with the increasing globalization of science $^{10}$.

Rest of this paper is structured as follows. In section 2.0, the author discusses the recruitment strategies and results for the first two cycles. Professional development and interdisciplinary cohort experiences are important components of our Site activities and are discussed in section 3.0. Exposure to interdisciplinary research is the key strength of this REU Site. Documentation of research results and their dissemination are critical for demonstrating effectiveness of the Site activities and play a critical role in Site renewal process. In section 4.0, these activities are described. Assessment of Site activities forms an important component of the REU Site work. A summary of our assessment work, conducted by external experts, is presented in section 5.0. In section 6.0, a brief summary of the research carried out by the REU mentees of the author is presented. Section 7.0 summarizes the paper along with lessons learned from the previous two cycles.

\subsection{Recruitment and Selection of REU Participants}

Each year, complete program announcement and application material were posted on our NSF REU website (www.lewas.centers.vt.edu). Brief announcements were sent to a variety of listservs for recruiting students from various institutions. Help was sought from the officials of the university in sending the Site announcement to listservs of potential students in the Historically Black Colleges and Universities (HBCUs) and 14 Native American service institutions. A webenabled application submission system was developed and implemented in fall 2012 and summer 2013 REU fellows submitted all application materials electronically. Participant selection criteria 
included academic records, two reference letters, and an essay about candidate's interest in interdisciplinary water research. The author did initial screening of applications and then made final selection in consultation with the faculty mentors ( 6 women and 5 men). We were successful in recruiting a diverse group of 56 highly qualified REU fellows (26 in 2007-09 and 30 in 201113) from a wide geographic area (Figure 1). As shown in Tables 1 and 2, our 56 REU fellows came from under-represented groups and smaller institutions as well as from large institutions and represented diverse academic backgrounds from various engineering and science disciplines. The majority of our program participants were juniors and rising seniors but included three rising sophomores.

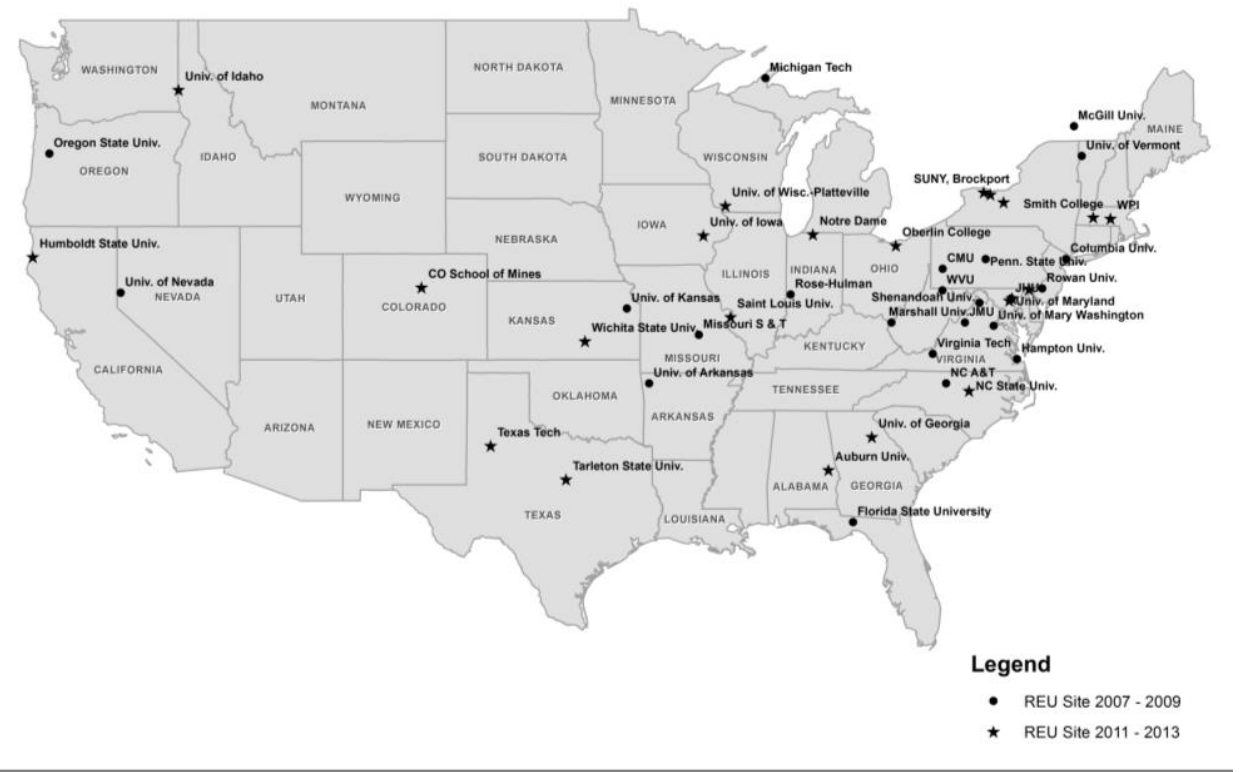

Figure 1. Geographic Diversity of NSF REU Fellows (2007-09; 2011-13)

Table 1. REU Fellows' Gender, Ethnic and Institutional Diversity: 2007-09 and 2011-13 Sites

\begin{tabular}{|l|c|}
\hline & $\begin{array}{c}\text { Total: }(07-09)(11-13) \\
(\% \text { total })\end{array}$ \\
\hline Total Recruited & $(\mathbf{2 6})(\mathbf{3 0})$ \\
\hline Female & $(16)(17)$ \\
& $(59 \%)$ \\
\hline Male & $(10)(13)$ \\
& $(41 \%)$ \\
\hline Ethnic Minorities & $(5)(5)$ \\
& $(18 \%)$ \\
\hline Small & $(7)(7)$ \\
Colleges/programs/ & $(25 \%)$ \\
HBCUs & \\
\hline
\end{tabular}

Table 2. REU Fellows' Academic Majors

\begin{tabular}{|l|c|}
\hline & $\begin{array}{c}\text { Total } \\
(07-09)(11-13)\end{array}$ \\
\hline Civil Eng & $(8)(7)$ \\
\hline Earth/Environ Eng & $(1)(5)$ \\
\hline Biological/Bio.Chem Eng & $(1)(2)$ \\
\hline Electrical/Comp. Eng & $(1)(1)$ \\
\hline
\end{tabular}




\begin{tabular}{|l|c|}
\hline Industrial Eng & $(1)(1)$ \\
\hline Eng. Science/Bio.Medical & $(1)(2)$ \\
\hline Comp. Sc. / Int. studies & $(1)(0)$ \\
\hline Environ Science & $(5)(4)$ \\
\hline Chem. /Chem. Eng. & $(2)(3)$ \\
\hline Biology/Ecology & $(3)(0)$ \\
\hline Marine/Integra. Science & $(1)(1)$ \\
\hline Geology/Physics & $(1)(4)$ \\
\hline Total & $\mathbf{( 2 6 ) ( 3 0 )}$ \\
\hline
\end{tabular}

\subsection{Professional Development and Interdisciplinary Cohort Experience}

\section{Orientation Sessions}

Each year, a 3-hour long orientation session including a group lunch was held on the first day of the Site. At this session, REU fellows met their research mentors and graduate students and got introduced to the REU program, participated in pre-Site assessment activities, accomplishments of prior year's REU fellows, expectations of the Site mentors and program director (author), and weekly professional development and social activities. Site research work began on day 2 . Typically, REU fellows worked in their mentors' labs Monday through Thursday. On Fridays, they participated in various professional development activities led by the author.

Weekly Seminars and Field Trips

REU fellows were required to attend weekly seminars and field visits lasting 2-5 hrs on Fridays. Examples of seminar topics are: 1) why research and how to do research; 2) effective library research; 3) how to read scientific literature critically; 4) professional ethics; 5) panel discussion with graduate students; and 6) environmental nanotechnology. For exposing REU fellows to water industry and use of emerging technologies in water research, field trips were organized to a Drinking Water Authority, a Wastewater Plant, Green Buildings in a neighboring city, local National Weather Service office, and a nanotechnology lab (i.e., Nanotechnology Characterization and Fabrication Lab) of an interdisciplinary research institute at Virginia Tech.

\section{Oral Presentations: Training}

Weekly seminars also provided an opportunity to REU fellows to practice their oral communication skills. All REU fellows made: 1) a 5-min. presentation about their research objective at the end of $2^{\text {nd }}$ week; 2 ) a 10-min. presentation (including research methods) at the end of week 6;3) a 15-min. presentation (including results) at the end of week 9 to their peers and the author. After each round of presentation, REU fellows critiqued presentations of their peers and provided written feedback to each other. Following quote from our assessment expert's summary ${ }^{11}$ validates the effectiveness of the communication aspect of our REU Site work:

"The communication aspect of the program is seen as quite positive, especially beginning with a brief presentation and building from there. Students report growing confidence in their own communication skills and observing improvement in the skills of others."

\section{Writing Research Papers: Training}

During the weekly forums, a special seminar was offered by the author to discuss the importance and process of good technical writing. Key issues in paper writing were emphasized throughout the program. REU fellows were provided with an author's guide to prepare their final research reports.

\section{Gaining Laboratory/Field Research and Latest Computing Skills}

REU fellows are provided with opportunities for field research, analytical laboratory work, computer modeling and testing of theoretical concepts. 


\section{Weekly Reflection Papers}

All REU fellows submitted weekly reflection papers using VT's course management software (Scholar) and reflected on their weekly research, social and cultural experiences. These papers were due by 10:00 p.m. on Thursday every week. The author reviewed these papers before meeting with the REU fellows at Friday seminars and answered questions.

\section{YouTube Videos}

REU fellows were divided into teams at the orientation session and were assigned to create YouTube videos (2-3 min) to document their research/social/cultural experiences. A YouTube competition was held at the concluding ceremony on the last day of the program. As of summer 2013, we have 7 YouTube videos of our REU program that we now use for recruitment. A sample YouTube video is available at: http://www.youtube.com/watch?v=zLXgAAriFb0

\section{Social Interactions}

The REU participants resided in an on-campus residential hall, with dining facilities, in two suites (one each for males and females) on the same floor. Each year we recruited one REU fellow from Virginia Tech which proved very effective in planning and implementation of social activities. Our REU fellows explored several local attractions and undertook weekend tours to neighboring cities. The author and his graduate students organized 2-3 picnics for social bonding each summer.

\section{Concluding Ceremony}

On the final day of the 10-week program, typically in August, a concluding ceremony lasting 4.5 hrs. was organized. All REU fellows made final research presentations to all faculty and graduate mentors at this ceremony. Several parents attended this ceremony. Students YouTube videos were screened and all attendees voted for the best videos. This ceremony followed a group lunch and Site work officially ended after this ceremony.

\subsection{The Research Program}

Interdisciplinary research is the unique strength of our REU Site. Eleven faculty representing civil and environmental engineering, engineering education, geosciences, biological sciences, and crop and soil environmental sciences and their graduate students mentored the REU fellows. Figure 2 shows a word cloud of the keywords from REU fellows' research papers in summer of 2011. Each year, a Research Proceedings ( 200 pages) was prepared that contained research papers and Site assessment results. These Proceedings are available at: http://www.lewas.centers.vt.edu/index.php/lewas-nsf-reu/past-reu-sites/past-proceedings

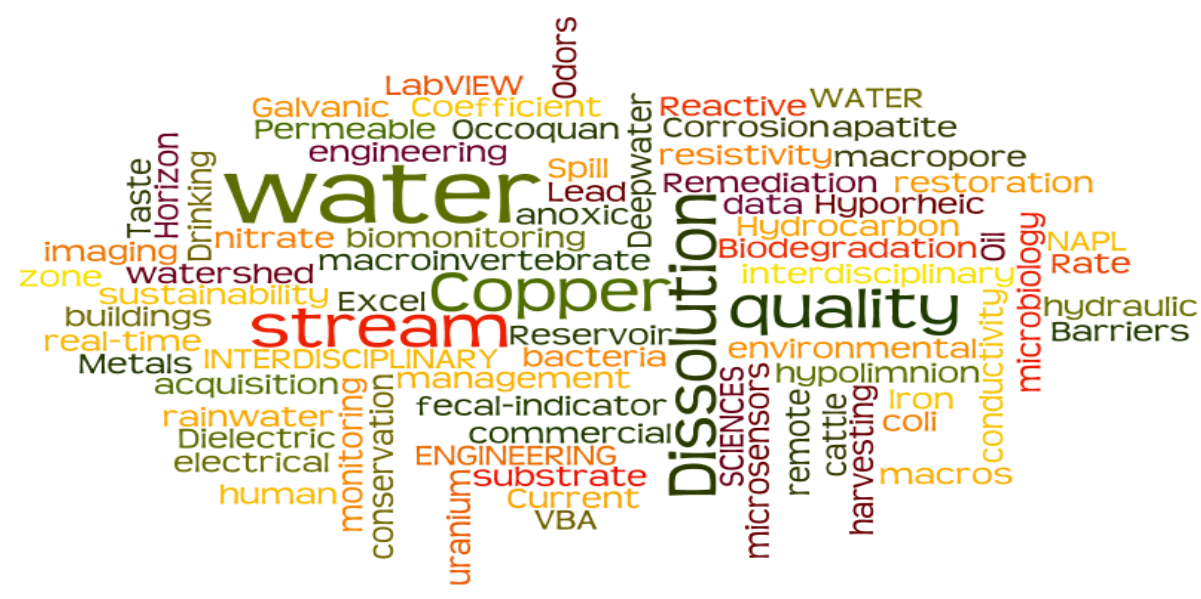

Figure 2: Word Cloud- Interdisciplinary Water Research, REU Site of summer 2011 


\subsection{Dissemination of Research Results}

In addition to the Research Proceedings, all REU fellows were encouraged to present their research findings at various national conferences. A list of conferences where our REU Sites' results have been presented includes AGU Fall Meeting, Geological Society of America Annual Meeting, Annual Conference of the American Society for Engineering Education, Conferences organized by the Council of Undergraduate Research (CUR), American Water Resources Association Spring Specialty Conference, Virginia/West Virginia Water Research Symposium, National SACNAS Conference, and World Environmental and Water Resources Congress. In addition, our REU Site-based research papers have been published or are being submitted to the following journals: Corrosion, Corrosion Science, Journal of the American Water Works Association, Archives of Environmental Contamination and Toxicology, Water Research, Frontiers in Microbiology, Journal of Environmental Monitoring, Computers and Geosciences, ASCE Journal of Waterway, Port, Coastal, and Ocean Engineering, and International Journal of Water (IJW). Beginning in summer 2012, VT began organizing a 1-day undergraduate research symposium for all undergraduate researchers ( 200) on the campus during the summer. Our REU fellows submitted extended abstracts for this symposium and all of them made 15-min long oral presentations at this symposium in summer 2012 and 2013. Lastly, the author presented summary of REU Site activities at various NSF Awardees conferences organized over the years.

\subsection{Media Attention of REU Fellow's Research}

In summer 2012, an REU fellow's research included analysis of recycled water samples which revealed that the pipe distribution system contributed to re-growth of bacteria carrying antibiotic resistance genes ${ }^{12}$. This attracted significant media attention. This same water she tested was piped to the Snow Bowl ski resort in Arizona starting Nov. 2012 for snow-making. There is also concern in the local community about the safety of using the water for spray irrigation of recreational fields. Spurred in part by the results of this REU project, an expert advisory panel on contaminants of emerging concern has been established by the City of Flagstaff in Arizona. Some news items related to this research are: (i) Cyndy Cole and Joe Ferguson, Wastewater Tests in Flagstaff Find New Concern, Arizona Daily Sun (Sept. 17 2012), (ii) Beth Buczynski, Making Snow with Recycled Sewage Could Breed Super Bacteria, New York Times (Oct. 17, 2012), (iii) Ashley P. Taylor, Manmade Snow from Recycled Sewer Water May Contain Antibiotic Resistant Bacteria, Discover Magazine (Oct. 16, 2012), (iv) Cyndy Cole, Water Experts to Convene Again, Arizona Daily Sun (Jan. 22, 2013).

\subsection{Program Assessment and Tracking of REU Fellows}

Two external assessment experts (Dr. John Muffo: an independent assessment consultant who was the director of academic assessment for 15+ years at VT and Dr. Julie Martin: an engineering education researcher at Clemson university) assisted in the assessment of our Site work. Assessment tools included online surveys, pre- and post-test questions, focus group interviews, and weekly reflection papers. Dr. Muffo led the assessment work during the 10-week summer session and has been our assessment consultant since 2007 and has submitted an assessment report to the author every year. These reports are available as part of our Research Proceedings. 5.1 Summary of Dr. Muffo's Assessment Findings ${ }^{11}$

Table 3 shows a 17-item pre-and post-test instrument that was developed for assessing effectiveness of our Site work. Dr. Muffo met with all REU fellows at the orientation session and also at the end of 10-week summer program and implemented the pre- and post-test surveys. He also conducted an hour long focus group session (see Table 3 for our focus group questions) with our REU fellows as part of our concluding day program. Based on analysis of assessment data over past three years $(2011,2012,2013)$, following two items showed highest gains (i.e., post-test scores - pre-test scores) over the 10-week research:

Item 10 (table 3): I have an appreciation for the role of faculty in research.

Item 11 (table 3): I have an appreciation for the role of graduate students in research. 
Following two items showed lowest gains (post-test scores - pre-test scores):

Item 5. (table 3) There are winners and losers in environmental conflicts; it's as simple as that. Item 7. (table 3) The use of statistics is not important in water research.

As an example, Figure 3 shows pre-and post-test results from our Site work in summer 2013.

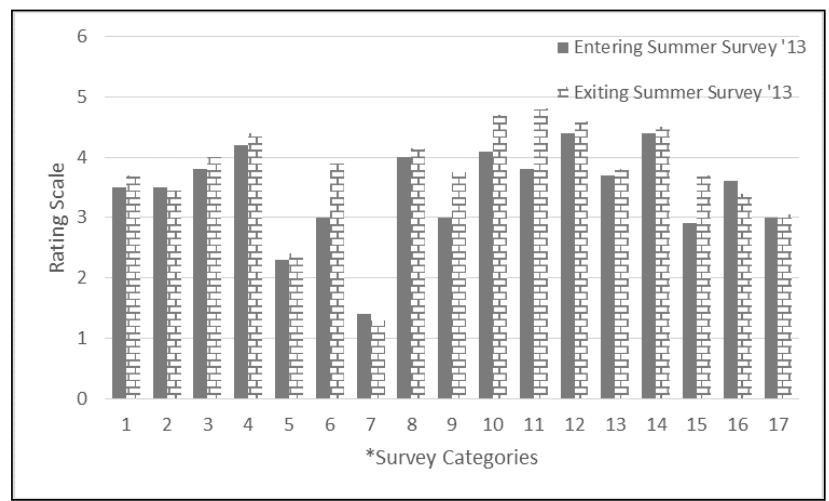

Figure 3. Results of 17-item pre-and post-tests $(\mathrm{n}=11)$ (summer 2013)

\section{Table 3: Pre-and Post-Test Questions}

Likert Scale: 1 = Strongly Disagree; 2 = Disagree; $3=$ Neutral $/$ No Opinion; $4=$ Agree; $5=$ Strongly Agree

1. I am confident that I understand how to conduct scientific research.

2. I know everything that I need to know to conduct research in the library.

3. I can communicate scientific concepts effectively to a scientific audience.

4. I have a good understanding of the role of ethics in scientific investigations.

5. There are winners and losers in environmental conflicts; it's as simple as that.

6. I understand the processes used to monitor water quantity and water quality.

7. The use of statistics is not important in water research.

8. I am aware of the many ways in which scientists serve their communities.

9. I am aware of the many ways in which scientists from different fields interact with each other in conducting research in water sciences.

10. I have an appreciation for the role of faculty in research.

11. I have an appreciation for the role of graduate students in research.

12. I have an appreciation for the role of faculty in advising students.

13. I am aware of many opportunities for employment in the water field.

14. Water research can be challenging.

15. I plan on going to work soon after I graduate.

16. I plan attending graduate school soon after I graduate.

17. Social network sites (e.g., Facebook, YouTube, etc.) are a good way to share scientific research results.

Focus Group Questions

1. What did you like about the program that you just completed?

2. What concerns do you have about the program just ended?

3. List the top three things that you learned (within and outside of your discipline) during this program. 4.a. How many of you are motivated to go to graduate school now? - did the NSF REU influence your motivation?

4.b. How many of you intended to go to graduate school at the beginning of the summer?

5. How do you think that your communication skills improved as a result of this program? [Probing questions - Verbal? Written? Facebook? YouTube? Other?]

6. In what ways, if any, did you find the field trips informative?

7. How satisfied were you with your living environment at this university? Your social/cultural environment?

8. Other comments? 
Based on Dr. Muffo's report at the end of summer 2013, the focus groups have yielded a reasonably consistent picture as well. Below is the summary of the focus groups findings ${ }^{11}$.

- Both the strength and the weakness of the program is that it does, in fact, simulate graduate school reasonably well.

- $\quad$ The standard components of the program such as the housing arrangements, social activities, field trips, and seminars are now well developed and receive high marks from the students. The program has matured to the point that the recent students have benefitted from prior experience and evaluation; most of the rough spots have now been smoothed out. More specifically: (i) The mutual support offered by the common housing arrangement receives high praise every year. There is a strong sense of group support that the students appreciate, especially since they are from different institutions of higher education, (ii) The diversity of students is appreciated as well, both academically and demographically. They find it more stimulating to be around each other in an intense situation where people have a wide variety of perspectives, (iii) They seem to take full advantage of the social activities offered in the town area in the summer, especially those outdoors, as can be seen in the student videos, (iv) The communication aspect of the program is seen as quite positive, especially beginning with a brief presentation and building from there. Students report growing confidence in their own communication skills and observing improvement in the skills of others, (v) The field trips are informative, even when things do not always go as planned. Sometimes that is as informative as when they do go as planned, and (vi) Likewise the seminars are found to be useful, though this year's students expressed a desire for more interaction in them.

In the end, Dr. Muffo tries to answer the question: Does the program encourage undergraduate students to attend graduate school? The likely answer, per Dr. Muffo, is ${ }^{11}$ :

"It gives them a realistic view of graduate school and, as a consequence, helps them make a better informed decision about whether or not to attend upon graduation. That does not necessarily mean that they are more likely to attend. Sometimes a better informed person will make a more nuanced decision. Some of the students report that they are even more convinced that traditional Ph.D. graduate level study is the best decision for them. Other students report that Ph.D. level graduate study is not a good fit for them, but that professional school, such as medicine or public health, would be better. Others report that they are not certain what direction they will take after undergraduate study, often planning to work for a year or two and to decide later or to take courses part-time while working. Others decide as a result of the experience that graduate study is not what they want to do after graduation. This tends to be a small group, i.e., those who rule it out altogether."

\subsection{Summary of Dr. Martin's Assessment Findings ${ }^{13}$}

Since Dr. Muffo assessed program outcomes on a regular basis, services of Dr. Martin were sought on "when needed" basis due to budgetary constraints. For example, she provided leadership in analysis of all weekly reflection papers (altogether 92 pages by 9 REU fellows in

summer 2012) at the end of 2012 Site work and submitted a report to the author that included six major themes ${ }^{13}$ :

1. REU participants' summer experiences were greatly enhanced by the excellent camaraderie among the participants and the social activities in which they engaged. 2. Communication with faculty mentor and graduate student mentors varied among participants and affected their research experience.

3. REU participants expressed learning various aspects of research and lab. 
4. Participants discussed how various aspects of the program influenced their academic and career plans.

5. The weekly forums and field trips were popular and eye-opening.

6. The incorporation of research presentations and final paper increased participants' perception of their communication skills.

This report was shared with all faculty mentors. In spring 2013, Dr. Martin developed a 25-item survey, in consultation with the author, to track academic/career progress of past REU fellows. All participants since 2007 were requested to complete the survey. Out of 45 alumni as of March 2013,25 participants responded to the survey. Below are some key findings from this survey ${ }^{13}$ :

1. $68 \%$ of respondents plan to obtain a graduate degree $(24 \% \mathrm{PhD}$ and $44 \%$ Master's)

2. $17 \%$ of respondents were pursuing a $\mathrm{PhD}$ degree when they completed the survey

3. $80 \%$ respondents will pursue a research career in engineering/science in the future

4. The REU has been influential (57\%) and highly influential (35\%) in their academic/career plans

5. Question: Please write a sentence or two about how the REU experience influenced your decision to pursue (or not pursue) GRADUATE SCHOOL in engineering or science. Sample responses:

"I was really turned on to the summertime graduate student lifestyle, which I got to observe very closely during the REU. I plan to pursue a graduate degree, and I expect to emulate the funspirited, hard-working attitude of the graduate students with whom I worked during my summer REU."

"I would say that the program helped me realize that graduate school at this time in my life would not be beneficial, probably mostly due to maturity. I think that the program helped me realize that down the road a PhD. may be something I would like to pursue."

\subsection{Author's REU Mentees}

During the two REU Site cycles, the author, along with his graduate students, mentored/comentored 9 REU fellows. Six of them with backgrounds in civil engineering, electrical and computer engineering, computer science, chemical engineering, environmental science, industrial engineering directly worked on a project that involves development of a real-time water and weather monitoring system (i.e., LabVIEW Enabled Watershed Assessment System (LEWAS)) on the campus of Virginia Tech ${ }^{14}$. This goal of the system is to enhance water sustainability education and research at VT. This system has sensors to measure water quality and quantity data including flow rate, depth, $\mathrm{pH}$, dissolved oxygen, conductivity, and temperature. This data can be used as an indicator of stream health for an on-campus impaired stream in real-time. In addition, weather parameters (temperature, barometric pressure, relative humidity and precipitation) are measured at the outdoor site of the system. All of these environmental parameters can be accessed by remote users in real-time through a web-based interface for education and research. This system is solar powered and uses the campus wireless network through a high-gain antenna to transmit data to remote clients in real-time. The REU fellows who worked on this project developed skills in LabVIEW programming and field work including data collection from field sensors, data analysis and equipment calibration work. Figure 4 shows a schematic of the work done by an REU mentee in summer 2013. The goal was to develop a LabVIEW enabled real-time weather monitoring system with an interactive database. This work is continuing at the time of this writing and the REU student continues to work in the author's lab. 


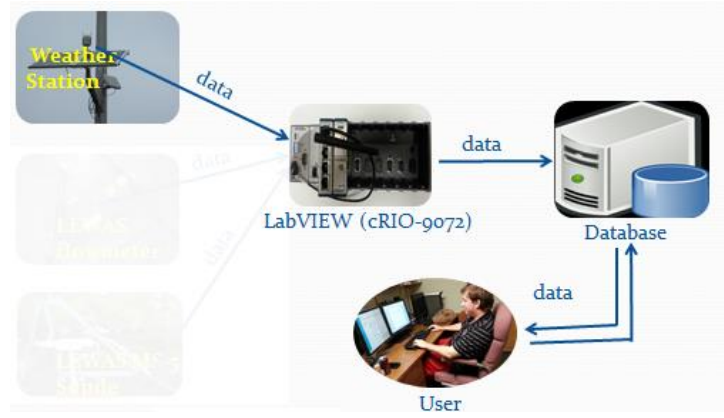

Figure 4: Author's REU Student's work in summer 2013

Examples of students' research work related to the LEWAS are given in papers ${ }^{15-19}$ that are part of the REU Site proceedings. It may be mentioned that the LEWAS is currently being used to enhance hands-on learning in a senior level Hydrology course at Virginia Tech and two freshman engineering courses at Virginia Western Community College, Roanoke as part of an ongoing NSF/TUES project ${ }^{20-23}$.

\subsection{Summary}

The REU Site on Interdisciplinary Water Science and Engineering has been fairly successful in stimulating students' research interests in interdisciplinary water sciences. It is a well-established REU Site now on Virginia Tech campus and has attracted attention of several new faculty mentors. For the $3^{\text {rd }}$ cycle of the Site (2014-16), five new faculty members have joined our research mentor team to bring new expertise related to water sciences. Examples of new research topics include ecosystem ecology, international dimension of water research, application of bioinspired techniques in water issues, environmental chemistry, and coastal engineering. Overall, we now have 11 faculty mentors ( 6 women and 5 men), representing four (Engineering, Agriculture, Science, and Architecture) out of eight colleges at Virginia Tech, engaged in interdisciplinary water research for mentoring 10 REU fellows. About 10 graduate students participate in mentoring REU fellows in conjunction with their advisors and receive valuable experiences in undergraduate research mentoring. This Site will continue for the next 3 years (2014-16). Example projects for summer 2014 include:

1. Evaluating the Efficacy of Water Quality Treatment on Cyanobacterial Blooms

2: Water Quality for Human Health and Aesthetics

3: Hydrology and Hydraulics Impacts on Ecological Health of Streams and Rivers

4: Quantification of distinguishing features of tsunami versus hurricane sediment overwash events

5: Bio-Inspired Water Stewardship Lab

6: Development and Implementation of a Raspberry Pi-based System for Processing and Remote Access of Real-Time Environmental Data

7: Biogeochemical Controls on Contaminant Transport and Transformation

8: Designing empowerment: Development of a community level hydro power generation solution for impoverished communities

9: Investigation of the occurrence and fate of 4-nonylphenol, an endocrine disruptor, in urbanimpacted watersheds

10: Mechanisms of Cupric Ion Control of Legionella in Premise Plumbing

The interdisciplinary nature of this Site and its success has encouraged the author and other faculty mentors to pursue other interdisciplinary NSF programs. For example, an NSF/Research 
Experiences for Teachers (RET) Site proposal and an NSF/Improving Undergraduate STEM Education (IUSE) proposal by a sub-set of faculty mentors are in review at the time of this writing. Lastly, lessons learned since 2007 are presented as below:

1. Structured professional development and cohort experience are critical to a successful REU program. Potential research projects and the work REU students will engage in must be defined clearly in the program announcement.

2. Program assessments at the beginning, throughout the 10 -week period, and at the end are critical to program success. Use of an external assessment expert brings credibility to assessment results and provides candid feedback.

3. Weekly reflection papers are an effective way to learn about REU fellows' experiences during the program and serve as an effective formative assessment tool.

4. A wider net and personal contacts increase the potential for increasing participant diversity.

5. Activities that promote social interaction and professional bonding among participants are as critical as the research activities.

6. Documentation of research outcomes in the form of a research proceeding provides a source for ownership and pride to REU fellows. Dissemination of REU Site outcomes should be taken seriously. REU Site Directors must explore multiple avenues for this purpose and encourage fellow faculty mentors and REU fellows for the same

7. Providing multiple opportunities for oral presentations helps REU fellows in improving their communication skills.

8. YouTube videos of the REU program are effective recruitment tools and provide ownership of the REU Site to REU fellows and gives them valuable experience in documenting/presenting their work.

\section{Acknowledgement}

The author is grateful to our outstanding 56 REU fellows from all over the country who worked very hard during their 10-week research work at our campus and made us very proud. Sincere thanks are to my colleagues (Drs. Edwards, Pruden, Dietrich, Irish, Hester, Dymond, Little, Widdowson in civil \& environmental engineering; Dr. Schreiber in geo-sciences; Drs. Xia and Hagedorn in crop \& soil env. sciences; Drs. Benfield and Carey in biological sciences; and Prof. Sharma and Kennedy in industrial design at VT) and their graduate students and lab personnel who are the key reason for the success of this REU Site. The author co-directed this Site with Dr. T. Younos during the first cycle (2007-09) and is very thankful to him. Our external assessment experts (Drs. Muffo and Martin) provided candid and timely assessment of our Site work that helped us in implementing continuous improvement of Site work. My sincere thanks are to our assessment experts. My LEWAS lab students (Parhum Delgoshaei, Daniel Brogan, Mark Rogers, Walter Mcdonald, Hari Raamanathan) who provided valuable assistance in implementing various activities of the Site are sincerely thanked. Finally, I acknowledge the support of the National Science Foundation through NSF/REU Site Grant EEC-1062860. Any opinions, findings, and conclusions or recommendations expressed in this paper are those of the author and do not necessarily reflect the views of the National Science Foundation. My sincere thanks to our program officer Ms. Esther Bolding at NSF for administering the REU program very well.

\section{Bibliography}

1. http://Www.engineeringchallenges.org/cms/8996/9142.aspx accessed on Sept. 10, 2013.

2. United Nations (2003). "Water for People, Water for Life." UN World Water Development Report. New York: UNESCO. 
3. Lohani, V. K., and T. Younos. 2008. Implementation and Assessment of an Interdisciplinary NSF/REU Site on Watershed Sciences and Engineering," Proc. 2008 ASEE Annual Conference, June 22-25, 2008, Pittsburgh.

4. Bolding, E. 2009, Research Experiences for Undergraduates, 2009 NSF Engineering Education Awardees Conference, Feb. 1-3, 2009, Reston, VA.

5. Raicu, D. S. and Furst, J. D., 2009. Enhancing undergraduate education: a REU model for interdisciplinary research, SIGCSE '09 Proceedings of the 40th ACM technical symposium on Computer science education, pp. 468-472.

6. Gonzales-Espada, W. J. and Zaras, D. S., 2006. Evaluation of the Impact of the NWC REU Program Compared with Other Undergraduate Research Experiences, 15th Symposium on Education, American Meteorological Society, Atlanta, January 2006

7. Labrador, M. A. and Perez, R., 2006. Fulfilling Mentors' Expectations: An REU Site Experience, 2006 ASEE Southeast Section Conference, Tuscaloosa, Alabama

8. Labrador, M. A. and Perez, R., 2006. Increasing the Participation of Under-represented Minority Student Groups in Computer Science and Engineering: An REU Site Experience, $36^{\text {th }}$ Annual Frontiers in Education Conference, 27-31 Oct., 2006, San Diego, CA.

9. Peckham, J., Mili, F., Raicu, D.S., and Russell, I., 2008. REUs: undergraduate research experiences and funding, Journal of Computing Sciences in Colleges, vol. 23 issue 5, May 2008, pp. 208-211

10. Beninson, L. A., Koski, J., Villa, E., Faram, R., and O'Connor, S. E., 2011. Evaluation of the Research Experiences for Undergraduates (REU) Sites Program, CUR Quarterly, fall 2011, vol. 32, no. 1.

11. Assessment Summary: NSF/REU Site: Interdisciplinary Water Sciences and Engineering, Submitted by Dr. John Muffo to Dr. Vinod K Lohani, August 3, 2013.

12. O'Brien, M., Mazzochette, M., and Pruden, A., 2012. Antibiotic Resistance Genes in Recycled Water, Proceedings of Research, NSF/REU Site on Interdisciplinary Water Sciences and Engineering, Virginia Tech, pp. 55-70.

13. Assessment Report: NSF/REU Site: Interdisciplinary Water Sciences and Engineering; Prepared by Dr. Julie Martin; Submitted to Dr. Lohani, 2013.

14. Delgoshaei, P. and Lohani, V. K., Design and Application of a Real-Time Water Quality Monitoring Lab in Sustainability Education. Paper accepted for publication, International Journal of Engineering Education.

15. Kenny, J., Delgoshaei, P. and Lohani, V. K., 2008. Integration of LabVIEW into Stroubles Creek Watershed Assessment, 2008 NSF REU Proceedings of Research Opportunities in Interdisciplinary Watershed Sciences and Engineering, pp.58-70.

16. Greer, D., Delgoshaei, P., and Lohani, V. K., 2011. LabVIEW Virtual Instrument Development and Implementation for Environmental Monitoring in Real Time, Proceedings of Research, NSF/REU Site on Interdisciplinary Water Sciences and Engineering, Virginia Tech, pp. 45-58.

17. Martinez, M., Bradner, A., Borgan, D., Rogers, M., Delgoshaei, P., and Lohani, V. K., 2012. Study and Application of a Real-Time Environmental Monitoring System, Proceedings of Research, NSF/REU Site on Interdisciplinary Water Sciences and Engineering, Virginia Tech, pp. 72-84.

18. Clarke, H., Mcdonald, W., Raamanthan, H., Borgan, D., Lohani, V. K., and Dymond, R., Investigating the Response of a Small, Urban Watershed to Acute Toxicity Events via RealTime Data Analysis, 2013. Proceedings of Research, NSF/REU Site on Interdisciplinary Water Sciences and Engineering (under preparation), Virginia Tech

19. Rai, A., Borgan, D., and Lohani, V. K., 2013. A LabVIEW Driven Real-time Weather Monitoring System with an Interactive Database, Proceedings of Research, NSF/REU Site on Interdisciplinary Water Sciences and Engineering (under preparation), Virginia Tech 
20. Dymond, R., Lohani, V. K., Brogan, D., and Martinez, M., 2013. Integration of a Real-Time Water and Weather Monitoring System into a Hydrology Course, Proc. 2013 Annual Conference of American Society for Engineering Education, June 23 - 26, 2013, Atlanta, GA.

21. McDonald, W. M., Dymond, R. L., Lohani, V. K. and Brogan, D. S., 2014. Insights and Challenges in Developing a Remote Real-Time Watershed Monitoring Lab, Proc. 2014 Annual Conference of American Society for Engineering Education (in review).

22. McDonald, W. M., Dymond, R. L., Lohani, V. K. and Brogan, D. S., 2014. Integrating a Real-Time Remote Watershed Monitoring Lab into Water Sustainability Education, Proc. 2014 Annual Conference of American Society for Engineering Education (in review).

23. Brogan, D. S., Lohani, V. K. and Dymond, R. L., 2014. Work-in-Progress: The Platform-Independent Remote Monitoring System (PIRMS) for Situating Users in the Field Virtually, Proc. 2014 Annual Conference of American Society for Engineering Education (in review). 